\title{
Toplumsal Değişme, Kişiler Arası Sözsüz İletişim ve Engellilik
}

\author{
DOI: $10.26466 /$ opus.836347
}

*

\begin{abstract}
Ayșegül Demir *
* Dr. Öğr. Üyesi, Sinop Üniversitesi, Fen Edebiyat Fakültesi, Sosyoloji Bölümü, Sinop/Türkiye E-Posta: ayseguldemir@sinop.edu.tr ORCID: 0000-0002-7328-4492

Öz

Toplumsal değişme, insanların varlık gösterdiği tarihsel toplumsal dünyanın dönüşümünü ifade etmektedir. Bu dünya, içerisinde konumlanan toplumsal yapı, toplumsal kurumlar, toplumsal ilişkiler ă̆ı, davranış kalıpları, toplumsal norm ve değerleri içermektedir. Tüm bunların gerçekleştiği günlük iletişimin büyük bir kısmı, konuşulan dilin dışında olan jestler, mimikler veya dilsel olmayan işaretler aracılığıyla gerçekleşmektedir. Toplumsal değişme ile birlikte sözsüz iletişim biçimlerinin de değişim ve dönüşüm geçirdiği çă̆ımızda engellilerin toplumsal iletişimi nasıl gerçekleştirdikleri önemli olmaktadır. Bu doğrultuda çalışma, toplumsal değişme sürecinde kişiler arası sözsüz iletişimin engelliler açısından görünümünü ortaya çıkarmayı hedeflemektedir. Çalışmada, engellilerin durumunu anlamlandırabilmek için, sosyolojik araştırmada nitel araştırma yöntemi ve örneklem olarak amaçl örnekleme kullanılmaktadır. Türkiye Sakatlar Derneği (TSD) Sinop Şubesi'ne üye toplam olarak, 9 kişi (üç kadın ve altı erkek) ile derinlemesine yapılandırlmamış görüşmeler yapılmıştır. Görüşmelerde veriler aktarılarken kodlama tekniği kullanılmakta ve kodlamalar, cinsiyet, yaş ve medeni durumlarına göre yapılmaktadır. Verilerin çözümlenmesi esnasında görüşmelerden elde edilen bulgular birincisinde; Toplumsal Değişme ve Beden Dili, ikincisinde; Kişiler Arası Sözsüz İletişim ve Engellilik olmak üzere iki ana tema ve ikinci ana temada; Göstergeler ve Yazı ve Ses ve Jestler olmak üzere iki alt temaya ayrllp betimlenmekte, yorumlanmakta ve değerlendirilmektedir.
\end{abstract}

Anahtar Kelimeler: Toplumsal Değişme, Kişiler Arası Sözsüz İletişim, Beden Dili, Engellilik 


\title{
Social Change, Interverbal Communication and Disability
}

\begin{abstract}
Social change refers to the transformation of the historical social world in which people exist. This world includes social structure, social institutions, network of social relations, patterns of behavior, social norms, and values. Most of the daily communication that takes place is through gestures, mimics, or non-linguistic signs that are outside the spoken language. Most of the daily communication that takes place is through gestures, mimics, or non-linguistic signs that are outside the spoken language. It is important how the disability of the disabled at the time of social change and non-verbal forms of communication are transformed and transformed. In this direction, the study aims to reveal the viewpoints of non-verbal communication among people in the process of social change. In the study, qualitative research method in sociological research and purposeful sampling as sample are used to understand the situation of the handicapped. Turkey Disabled Association (TSD) as a member of the Sinop Branch of the total, nine people (three women and six men) with in-depth unstructured interviews were conducted. Negotiation uses coding technique when transferring data and coding is based on gender, age, and marital status. During the analysis of the data, the findings obtained from the interviews are Social Change and Body Language; There are two main themes and the second main theme; Non-verbal Communication and Disability; It is divided into two sub-themes: Indicators and Writing, Voice and Gestures, and is described, interpreted, and evaluated
\end{abstract}

Keywords: Social Change, Non-verbal Communication Between Individuals, Body Language, Disability 


\section{Giriş}

Bir değişim dinamiği olan birey, modern toplumun temel aktörü konumundadır. Bireyin yeni toplumsal bağlar kurmasında ben merkezli egosunu toplumsallaştıracak yeni ilişkilerin, iki önemli boyutu bulunmaktadır. Birincisi, elde ettiği başarıların özgüvenini geliştirmesi ve bu özgüven duygusunu besleyen yeni manevi kaynaklarm toplumsal olarak üretilmesidir. İkincisi ise, birey merkezli bir manevi inanç dünyası yaratarak bireysel gelişmeye katkıda bulunmasıdır. Buradaki birey, toplumsal sorumlulukları, toplumsal duyarlılığı olmayan bencil birey değil, toplumsallığını bu yeni çerçevelerde üreten ve değişimin aktörü olarak tarih sahnesinde yeni bir rol alan insandır (Bilgin, 2007, s. 30-31).

İnsan bedenlerinin toplumda arzı oplumsal ilişkiler aracılığıyla gerçeklik kazanmaktadır. Bedenlerin topluma arzına ya da toplum sahnesinde konumlanmasına bakıldığında, epey karmaşık bir süreç göze çarpar. Karmaşıklı̆̆ın temeli ise, birbiriyle karşılaşan bedenlerin aynı zamanda etkileşimi ve birbirine yapılan müdahaleda ya da güçlünün zayıfla iç içe girmesinde yatmaktadır. Gündelik yaşamda beden, toplumsal olarak iletişim, iktidar ilişkileri ve sınıfsal ilişkiler gibi oldukça etkili olmaktadır. Ayrıca, istenildiği şekilde beden sahibi ile toplum ya da toplumun farklı aktörleri tarafından beden etki altında tutulabilmektedir. Beden bir iletişim dili, aracı ya da mekânı olarak çevresini etkilemek ve diğer insanlara mesaj vermek amaciyla küçük ve büyük müdahalelere görece olarak uğramaktadır. Müdahalenin bu hali, doğrudan bedene sahip olanın kişinin kendisi tarafından ya da başka aktörler tarafından yapılmaktadır. Böyle örnekleri gündelik yaşamın gerçekliği içinde insanların bedenleriyle farklı şekillerde meşgul olarak topluma mesaj vermelerini daima gözlemek olanaklıdır (Okumuş, 2009, s. 47).

Bu durumu, toplumsal değişim ile ilişkilendirmek gerekir. Toplumsal değişim, toplumun yapısını meydana getiren toplumsal ilişkiler ağının ve bu ağı belirleyen sosyal kurumların zaman ve mekân içerisinde farklılaşmasını ifade etmektedir. Bazı değişmeler; toplumsal rol ve statülerdeki değişmeler, ekonomik yapıdaki değişimler, (nüfus artış hızındaki değişmeler, üretim ilişkilerindeki değişmeler, dinsel yapıdaki değişmeler, aile ve akrabalık ilişkilerindeki değişmeler, gelenek ve göreneklerdeki değişmeler, çocuk yetiştirme yöntemlerindeki değişmeler) toplumsal değişme kapsamı içinde yer almaktadır (Aydın ve Baran, 2010, s. 117). 
$\mathrm{Bu}$ değişmeler içerisinde engellilik imgesi, toplumsal boyutun dışında normal olarak addedilen sağlam ve eksiksiz bir beden algısıyla uzun bir süre boyunca medikal bir anlam taşımıştır. Engellilik ile ilgili sosyal hareketlerin yaygınlaşmasıyla bu anlayış değişim göstermiştir. Engellilik ile ilgili olarak 'impairment' (yeti yitimi), bir ya da daha fazla uzvun kısmen, tümüyle eksik ya da işlevsiz olması anlamına gelirken 'disability' (engellilik), daha çok toplumsal ve mekânsal pratiklerin, sözü edilen bedensel farklılıkların göz ardı edilmesi sebebiyle gerçekleşen kısıtlamaları ifade etmektedir. Burada, engelliliğin toplumsal inşası ön plana çıkarılmakta, engel bedende değil toplumsal alg1 biçiminde aranmaktadır (Uluocak ve Aslan, 2012, s. 33-37).

$\mathrm{Bu}$ algı biçiminde kişilerarası yüz yüze ilişkiler ve beden dilinin oldukça önemli bir rolü olmaktadır. Bu ilişkilerde hiçbir söz söylenmemiş olsa da bedenler konuşmaktadır. Yüz yüze iletişimin inşasında sözcüklerin ve ses tonunun, beden dilini oluşturan mimik, jestler ve kişiler arası ilişkilerin ve iletişim ortamını özelliklerine göre beden dilinin iletişimdeki rolü önemli olmaktadır. Birey hem toplumsal hem de kültürel bir varlık olduğu için beden dili de kültürel olmaktadır. Sosyalleşme sürecinde beden dili öğrenilir, biçimlenir ve aktarılır. Bu sebeple, beden dilinde her kültürün birikimini görmek mümkündür. Böylece, beden dili bir toplumun kültürel olarak seçimler yaptığı, değerler belirlediği, hiyerarşi kurduğu ve onayladığı, yargıları temellendirdiği bir örnek niteliğindendir. Bu örnek, engelli bireyler için de içinde bulunduğu toplumun parçası olarak bireysel tercihlerini, zevklerini, duyma ve düşünme biçimlerini ortaya koyabilecek seçimler sunmaktadır (Kocasavaş, 2007, s. 50).

Kısaca, toplumsal değişme, insanların varlık gösterdiği tarihsel toplumsal dünyanın dönüşümünü ifade etmektedir. Bu dünya, içerisinde konumlanan toplumsal yapı, toplumsal kurumlar, toplumsal ilişkiler ağı, davranış kalıpları, toplumsal norm ve değerleri içermektedir. Tüm bunların gerçekleştiği günlük iletişimin büyük bir kısmı, konuşulan dilin dışında olan jestler, mimikler veya dilsel olmayan işaretler aracıllğıyla gerçekleşmektedir. Bu işaretler, bilginin üretiminde ve dağılımında toplumdan topluma, kültürden kültüre, cinsiyete kadar birçok değişkende farklılık gösteren kişiler arası sözsüz iletişim biçimlerini kapsamaktadır.

Bu değişim içerisinde engelliler, toplumsal yaşamda sözsüz iletişimi beden dilini bir zorunluluk olarak deneyimleyen önemli bir dezavantajlı grup 
olarak bilinmektedir. Toplumsal değişme ile birlikte sözsüz iletişim biçimlerinin de değişim ve dönüşüm geçirdiği çağımızda işitme engellilerin toplumsal iletişimi nasıl gerçekleştirdikleri önemli olmaktadır. Bu doğrultuda çalışma, toplumsal değişme sürecinde kişiler arası sözsüz iletişimin engelliler açısından görünümünü ortaya çıkarmayı hedeflemektedir.

Sonuç olarak, toplumsal değişme sürecinin önemli bir iletişim biçimini oluşturan kişiler arası sözsüz iletişimin işitme engelliler açısından yaşamsal olarak önemi kaçınılmaz olmaktadır. Bu süreçte toplumun bu iletişim biçimini kendi içlerinde sıklıkla kullandıkları fakat işitme engelliler açısından öneminin tam anlamıyla farkında olmadıkları görülmektedir. Çoğunlukla hayatı kolaylaştırmak için kullanılan sözsüz iletişim biçimleri esasında, işitme engelli bireylerin hayatının tamamını kapsamaktadır.

\section{Yöntem}

Çalışmada, işitme engellilerin durumunu anlamlandırabilmek için, sosyolojik araştırma yöntemlerinden nitel araştırma kullanılmıştır. Nitel veri, çekiciliği inkâr edilemez bir araştırma yöntemi olarak görülmektedir. Nitel verinin şimdiye kadar en yaygın biçimi olan kelimeler, insanların ve örgütlerin özel bir niteliği olmaktadır. Nitel verinin toplanmasında çoğunlukla anlaşılırlık ve basitlik bulunmaktadır. Raporlara gerçeğe benzerlikleri ile katkı sunmaktadır (Rabson, 2015, s. 575).

Çalışmanın verileri, 2020 yılından öncesine ait, süresi geçmiş zaman olarak belirtilen 2017 yllında toplanarak tamamlanmıştır.

\section{Örneklem}

Nitel araştırmalarda amaçlı örnekleme yöntemleri kullanılmaktadır. Amaç, benzerlik, farklılık ve çeşitlilik gibi unsurları göz önünde bulundurarak araştırmaya uygun amaçlı bir örneklem seçmek; araştırma konusu, sorusu, problemi hakkında bütüncül bir resim elde etmektir. Bu yönüyle oldukça hassas veya çalışılması zor popülasyonların araştırılmasını kolaylaştırmaktadır (Seggie ve Bayyurt, 2015, s. 28). Çalışmanın örneklemini, Sinop ilinde Türkiye Sakatlar Derneği'ne üye engelliler oluşturmaktadır.

Çalışmada nitel veri toplama tekniği olarak sorun-merkezli görüşme tekniğinin kullanılması uygun görülmektedir. Sorun merkezli görüşme, öznel anlamları kişinin kendi formülasyonları ışığında görebilmek üzere karşılıklı 
konuşma yolunu seçmektedir. Bunun için görüşmeci ile görüşülen kişi arasında güven ortamının sağlanmış olması gerekmektedir. Görüşme, nesnel durumu önceden araştırılmış belirli bir toplumsal sorun üzerine oturtulmaktadır. Görüşülen kişiler, belirli bir görüşme çerçevesinde bazı sorularla yönlendirilebilseler de, tepkilerini serbest ve belirli şıklara bağlı olmadan aktarabilmektedir (Mayring, 2011, s. 75).

\section{Verinin işlenmesi, Yorumlanması ve Çözümlenmesi}

Veri işleme tekniği olarak seçilen betimsel kayıt, görüşmelerin çözümlemesi de verilerin özgün şekline sadık kalınarak, bireylerin söylediklerinin doğrudan alıntısının betimsel bir analizle ve yaklaşımla sunulmasıyla yapılmaktadır. Görüşme çözümlerinde tanımlayıcı analiz mevcut olan kelime, ifade, kullanılan dil, diyalogların yapısı ve özelliklerinde kullanılan sembolik anlatımlar ve benzetmeler üzerine yapılmaktadır (Kümbetoğlu, 2005, s. 154).

Verilerin yorumlanması aşaması, temellendirilmiş kuram çözümlenmesinde kullanılan seçici kodlama ile yapılmaktadır. Bu merhalede araştırmacı bilinçli bir şekilde, asıl kategori olarak bir özelliği belirlemekte ve onun üzerinde yoğunlaşmaktadır. Bu seçim yapıldığında, kategori ilişkili verilerle sınırlanmakta ve açık kodlama sona erdirilmektedir. Seçici kodlamada amaç, gelişmekte olan çözümlemeyi bütünleştirmek ve bir araya getirmektir (Punch, 2014, s. 205).

Türkiye Sakatlar Derneği Sinop Şubesine üye toplam olarak, 9 kişi (üç kadın ve altı erkek) ile derinlemesine yapılandırılmamış görüşmeler yapılmıştır. Görüşmelerde veriler aktarılarken kodlama tekniği kullanılmakta ve kodlamalar, cinsiyet (Kadın: K, Erkek: E), yaş $(38, \ldots)$ ve medeni durumlarına (Bekar: B, Evli: E, Boşanmış: B) göre yapılmaktadır.

Verilerin çözümlenmesi esnasında görüşmelerden elde edilen bulgular birincisinde; Toplumsal Değişme ve Beden Dili, ikincisinde; Kişiler Arası Sözsüz İletişim ve Engellilik olmak üzere iki ana tema ve ikinci ana temada; Göstergeler ve Yazı ve Ses ve Jestler olmak üzere iki alt temaya ayrılıp betimlenmekte, yorumlanmakta ve değerlendirilmektedir. 


\section{Bulgular}

Verilerin çözümlenmesi esnasında görüşmelerden elde edilen bulgular birincisinde; Toplumsal Değişme ve Beden Dili, ikincisinde; Kişiler Arası Sözsüz İletişim ve Engellilik olmak üzere iki ana tema ve ikinci ana temada; Göstergeler ve Yazı ve Ses ve Jestler olmak üzere iki alt temaya ayrılıp betimlenmekte, yorumlanmakta ve değerlendirilmektedir

\section{Toplumsal Değişme ve Beden Dili}

Toplumsal değişme, göreceli olarak daha sabit ve durağan olan statü, rol, sosyal tabakalaşma ve sosyal kurumlar gibi sosyal örüntülerin yanı sıra teknolojik yeniliklerden bürokrasinin gelişimine, şehirlerin büyümesine kadar hayatımızı şekillendiren dinamik güçlere kadar tüm süreçleri kapsamaktadır. Bütün bunlar kültürün ve toplumsal kurumların zaman içindeki dönüşümünü ifade eden toplumsal değişimin boyutlarını oluşturmaktadır. Toplumsal değişim, sürekli olan, bazen kısıtlı ancak plansızca gelişen, karşıtlık içeren bir süreç içermektedir (Macionis, 2015, s. 627).

Bu değişim sürecinde toplumun bedene bakışı ve engelli bireylerin kendi bedenlerini algılayışının önemli olduğunu bir kadın şu şekilde ifade etmektedir:

"Ĕ̆itim çokönemli burada. Eğitimli bir kişi, mesela siz engelli değilsiniz ama ben engelliyim. Benim engelli oluşum sizinle iletişime geçmeme engel bir durum mu? Değil. Sizin beni anladı̆̆ınızı hissediyorum. Aynı şekilde sırf engelli diye beni anlayan insan olmayabilir ama olabilir de. Tabi ki ben burada ayırım yapmiyorum. Engelli insan, engelli olmayan insan fark etmez. Benim gibi hani engelli olursa, aynı duyguları paylaşırsak, kendimi daha iyi ifade edebilirim" (K, 38, E).

Burada geçen "Benim engelli oluşum sizinle iletişime geçmeme engel bir durum mu?" ifadesinden de anlaşıldığı gibi, engelliler normal olarak niteledikleri insanlardan fiziksel, fizyolojik ve nörolojik-kontrol farkl1liklarının kişilerarası iletişime engel olmadığını düşünmektedirler. Çünkü insanların birbirleri ile girmiş oldukları etkileşimde, bedenlerin hareketlerinin yanı sıra dil, sözcükler, ifadeler, işaretler gibi sembolik göstergeler önemli rol oynamaktadır.

"Genelde utanıyordum biliyor musunuz? Onu da yaşadım kendimde. Engelliyim ya hani o gözle, o şeyle bakarlar diye genelde hafif hafif saklanırdım. Sonra sonra 
insanlar yeniyor, yani her şeyi. Mesela insanların davranışları; kaza mı geçirdiniz, romatizma mi var? Genelde romatizmalılarda şekil bozuklukları oluyor ya onu sorarlardl. Ben de benimle düzgün iletişim kurana anlatıyordum, doğuştan diyordum, geçiyordum" (E, 22, B).

Burada, toplum tarafından inşa edilen bedenin genel olarak, genç, esnek, bronzlaşmış, sıkı tenli, hijyenik ve formda olması beklenmektedir. Deriye yüklenen anlam ise, düz ve parlak olması, kişisel biyografiyi yansıtan izler, kırışıklıklar, lekeler taşımamaıdır. Ayrıca bu ten, kokmayan, terlemeyen, pürüzsüz adeta klimatize edilmiş tazelikte kalarak delikler, yarıklar, benler, sivilceler, lekeler gibi kusur sayılan özelliklerden rrak bir şekilde kaygan olan bir deri niteliğinde olmalıdır. Şık bir ambalaj kâğıdı gibi daima taze kalması ve ölümsüzlük taşıması beklenen bu soyut yüzey, deriye yapıştırılan izler olduğunda onun için bir değişim ve gösterge değeri kazandırmakta, beden fetişleşmektedir (Çabuklu, 2004, s. 102-103).

Bu açıklamalar doğrultusunda, aşağıda verilen örnekte geçen “Özürüm bırakın benim özelliğim olsun" ifadesinde görüldüğü gibi engelli bireyler, kendi bedenlerine bir değişim ve gösterge değeri kazandırmakta ve engelliliği yeniden anlamlandırmaktadırlar:

“Özürüm bırakm benim özelliğim olsun, bununla kendimi insanlara armdırıp bir paye çıkarmam. Yani olabilir. Şimdi ne olur elbise sökülür, ne yapıyoruz terziye götürüyoruz değil mi dikilsin diye. Yani bu beden de bunun gibidir, önemli olan ruhtur. Tabii ki fiziksel güzelliği de aramıyoruz desek yalan olur. Bu da önemli ama bunun yanında önemli olan nedir? Ruhunuzu güzel şeylerle besleyebilmek. Nasıl bir elbise söküldü̈̆̈̈̈nde tadilat yaptırlabiliyorsa bedenimizde de olan çatlak patlakları doktorda düzeltebiliyoruz" (E, 41, Bo).

Böylece, kişilerarası iletişim açısından oldukça önemli bir yerde konumlanan beden dili, kişilerarası karşılıklı ilişkiler esnasında sözsüz olarak iletişimi gerçekleştirmektedir. Bir tek sözcük dahi kullanmadan kurulabilen bu iletişim türünde, ileti aktarım beden ve yüz özelliklerinin kullanılmasıyla sağlanmaktadır. Kişinin kendisini anlatması esnasında ihtiyaç duyduğu bedeni, sözcüklerle güçlü bir bütünlük sağlayacak biçimde oluşturması iletişime son derece önemli katkılar sağlayacaktır. Böylece, sözlü ve sözsüz iletişimin iç içe geçmesi yoluyla etkili iletişimin inşa edilmesi olanaklı hale gelecektir (Akgül, 2006, s. 25).

Bireyin fiziksel, fizyolojik, nörolojik-kontrol yetersizliklerinden biri veya birkaçı farklı oranlarda kendisini etkileyebilmektedir. Bu durumda, işitme, 
görme ve dokunma kanallarının kullanımı etkilenmekte ve bilgi edinimi farklılaşarak sinırlanabilmektedir. Bilişsel bozukluklar ile bir ek yetersizlik birleştiğinde bireyin yazıll, sözlü ve işaret dili olarak sıralanabilecek birçok iletişim modunun kapasitesi sınırlanabilmektedir. Her bireyde yetersizliklerden etkilenme oranları birbirinden farklı olduğu için bireyler birbirinden tamamen farklı ve benzersiz gereksinim oluşmaktadır (Küçüközyiğit ve Şafak, 2015, s. 27).

Bu ihtiyaçların bir yönü olan işaret dili kurslarının sivil toplum kuruluşları aracılığıyla engelli bireylere hizmet sunularak karşılanması bir kadın tarafindan şöyle dile getirilmektedir:

"İşaret dili kursu da verildi. Hâlâ daha devam etmekte. İşitme engelli arkadaşlarımızın için baya bir sıkıntısı vardı. Hani okuma ile ilgili bilgiye erişim ileilgili. Şimdi burada işaret diliyle her şeyi öğreniyorlar. Çok güzel oldu bu konuda" (K, 62, D).

$\mathrm{Bu}$ anlamda işaret dili, engelli bireylerin toplumla iletişimi ve etkileşimi açısından önemli bir araç niteliği taşımaktadır. Birleşmiş Milletler Engelli Hakları Sözleşmesi'nin üçüncü maddesinde iletişim ve dil ile ilgili olarak ifade edilen "iletişimin erişilebilir bilgi ve iletişim teknolojisi dâhil dilleri, metin gösterimini, Braille alfabesi kullanarak ve dokunarak iletişimi, büyük harflerle baskıyı, yazılı, işitsel ve erişilebilir çoklu medyayı, sade dili, işitsel okumayı, beden dilini, diğer tür, biçem ve araçlarla gerçekleşen iletişimi" bilgisi esasında hukuki anlamda da iletişimi tanımlamaktadır (Resmi Gazete, 2009).

Bu anlamda, kişiler arası etkileşimde sözsüz iletişim ve dil unsurlarının birbirlerini bir katalizör gibi tamamladıkları söylenebilir. Özellikle işitme engelliler için bu bağlam oldukça önemli bir değer taşımaktadır. Ayrıca sosyal engellilik olarak ifade edilen bakış açısında, artık işitme engeli bireyleri tanımlama ve anlama hususunda kullanılan tek yaklaşım tıbbi tanımlama ve kıstaslar olmamaktadır. Öyle ki, erişim ve katılım engellilerin toplumla etkileşimi ve bütünleşmesinde temel belirleyici kavramlar olmaktadır. Tibbi model, bireyin yetersizliğini bir 'kişisel sorun' olarak ele alıp yalnızca belirli meslek uzmanlarının ilgi alanı olarak görmektedir. Günümüzün anlayışına bakıldığında, sosyal engellilik bakışı ile yetersizliği olan bireyin eşit bir vatandaş olması gerektiği düşüncesinden hareketle bir 'toplumsal sorun' olarak görülmeye yönelmektedir (Kemaloğlu, 2014, s. 51; Güven, 2019, s. 967). 


\section{Kişiler Arası Sözsüz İletişim ve Engellilik}

Göstergeler ve Yazı: Gösterge, birey için sahip olduğu nitelik sebebiyle bazı açlardan başka bir şeyi temsil eden bir şeydir. Bir gösterge önce bir kişiye yönelmektedir. Başka bir ifadeyle, bu kişinin zihninde eşdeğerli ya da daha gelişmiş bir gösterge oluşturmaktadır. Bu göstergeye, birinci göstergenin yorumlayıcısı denmektedir. Gösterge, başka bir şeyin yerini tutmaktadır. Yeri tutulan bu şey onun nesnesi konumunda olmaktadır. Fakat, gösterge yerini tuttuğu bu şeyi her bakımdan temsil etmeyen, bir tür kavrama gönderme yaptığ1 şeydir (Akerson, 2005, s. 110).

Haklar temelindeki değerlendirmeler, kanunlar, tüzükler, yasa burada kişiler arası etkileşim aracı olarak kullanılan göstergeler olmaktadır. Bu göstergelerin engelliler açısından ifade ettiği anlam bir erkeğin sözlerinde şu şekilde belirtilmektedir:

"Bütün yasalarla devlet büyükleri her şeyi dört dörtlük yapsa sivil toplum örgütlerine ihtiyaç kalmazdr. Eksiklikleri göstermekle biz mükellefiz. Onlarn çözümü noktasında bir şeyler yapmaya çalışıoruz. Artık karnnca kararınca yapabildiğimiz kadar elimizden geleni yapryoruz. Çeşitli platformlarda yer alıyoruz. İste toplantılarda diğger derneklerle karşılaşıyoruz. Etkinliklerde karşılaşıyoruz. Birlikte hareket etmeye çalışıyoruz. Uygulamada şöyle bir sıkıntı var. 5378 sayıl bir engelliler yasası var. O yasaya göre, yasanm uygulamasinda bir sıkıntı var. Yasa da normalde çok güzel bir yasa. Diyor ki, kamusal alanları diyor, engellilere uygun hale getireceksiniz diyor ama böyle bir yasak olmasına ră̆men cezai müeyyidesi de olmasına rağmen. Bakanlik hatta bir kuruma ceza kesmişti ama uygulaması aşamasinda bir sıkıntı var. Yoksa yasanın içeriğinde bir problem yok yani" (E, 39, Evli). Bir kitle iletişim araçları olarak kuruluşların sosyal sorumluluk anlayışı dorultusunda uyguladıkları, reklam kategorisinden biri olan kamu spotunun engellilere ilişkin toplumsal algı üzerinde önemli etkisi bulunmaktadır. $\mathrm{Bu}$ reklamlar, zararlı alışkanlıkların önlenmesi, çevre ve doğanın korunması, hastalıklara ilişkin vatandaşların bilinçlendirilmesi, eğitime yönelik kampanyalar, kamu yararına çalışan derneklerin desteklenmesi gibi amaçları gerçeleştirmek üzere düzenlenmektedir. Kamu spotları, geniş bir biçimde planlanmış, medyanın bir parçası olarak görülmektedir. Gerek kamu spotlarında yer alan bireylerin gerekse de dış ses ve göstergelerin gerçekçiliği arttırmak ve izleyicilerin kendisine ait bir öğeyi spotlarda yakalamasını kolaylaştırmak 
kamu spotlarına ait olumlu bir özellik olarak gösterilmektedir (Yaman ve Gökcan, 2015, s. 56-57).

Engellilere göre bir gösterge aracı olarak kamu spotu uygulamasının kullanılarak kitle iletişim araçları vasıtasıyla toplumda kalıplaşmış belli yargıların önüne geçilmesi gerektiğini bir erkek sözleriyle aşağıdaki gibi ifade etmektedir:

"Bu şekilde yerel televizyonlarda olabilir ya da normal kanalda da olur bu şekilde. Düşünün açklıyorlar kimin işte pazar günü, konseri var, bedavadır hepinizi bekliyoruz. Ayn bunun gibi onun yerine de bir aile bilinçlendirme sempozyumu mu diyeyim, işte toplantısı mı diyeyim işte sosyal faaliyet mi diyeyim belki kü̧̈ük küçük şekilde katılım olacaktır diye düşünüyorum. Bir sigaranın kamu spotu var değil mi? Hani reklamı var. Hani yapabilirsin baba diyor ve öksürüyor. Yani buna benzer o an sanki engelli bir insana işte ha bunu yapabilirsiniz, şunu yapabilirsiniz, hani bu şekilde bir kamu spotu gibi destek verilebilir. Engelliye yapabilirsin evladım, edebilirsin gibi bir şey olabilir çünkü bir yere çıkamayan engelliyi alı kucağına oturtmak, oraya koymak doğru değil" (E, 63, B).

Ayrıca yaşlı bireylere ilişkin, hizmet açısından programların daha kapsamlı olduğu diğer toplum kurumlarının araştırılması, bakımda sorumlu ailelere yardım amacıyla kamu ve özel girişimcilerin cesaretlendirilmesi, bakımı vermek için destek servisleri ve meslek ilanlarının verilmesi, vaka yönetimi ve hizmet sunumuna ilişkin kamu çalışanlarına temel eğitim verilmesi, hizmet çalışanlarına, kapıcılara ve topluma eğitimler verilmesi gerektiği ortaya çıkmaktadır. Yaşlılar açısından, sosyal hizmetler ve sağlık hizmetlerinin yeterliliğinin sağlanması, mental sağlık ve aile danışmanlığı hizmetleri başta olmak üzere gerekli tüm danışmanlık hizmetlerinin oluşturulması, alkol ve zararlı madde kullanımını tedavi etme programlarının oluşturulması, bütün yaşlılara hak aramaya yönelik kendini savunma eğitiminin verilmesi, yaşlanmanın pozitifliği ve üretkenliği ile ilgili bilinçlilik oluşturulması ve eğitim yapılması konuları ön plana çıkmaktadır (Kıssal ve Beşel, 2009, s. 363).

"Illerde bizim çok konuştuğumuz şey var, burada engellilere bakım evi yapılması devlet tarafindan. Bu hala doğru dürüst gündeme gelmedi veya gelse bile çok az yerde var. Bu tip yerlerin, yaşl bakım evlerinin açılması gerekiyor. Sadece engellilere hizmet verecek" (E, 56, E).

Bu doğrultuda kurumsal sosyal sorumluluk kampanyalarının toplum için değer üretmek ve toplumdan alınanların belli bir bölümünü yine toplumun 
yararına kullanmak için yapıldığı görülmektedir. Günümüzde bilinçli tüketiciler için bir kurumun sadece kampanya yapması yeterli olmamakta, 'ne' yaptığı daön plana çıkmaktadır. Çünkü toplum için yarar sağlama bilinci, toplumun gerçek gereksinimlerine ilişkin yapılmaktadır. Aksi takdirde yapılan çalışmalar toplum yerine kurum için yapılmış olmaktadır. Öte yandan kampanyaların doğru ve eksiksiz bir şekilde yönetilmesi gerekmektedir. Doğru yönetilmemiş olan kampanyalardan kurum ve toplum zarar görebilmektedir (Bat, 2015, s. 2).

Bir sosyal sorumluluk kampanyası olarak ortaya çıan mavi kapak kampanyasının engellilerin yararına kullanılmak için yapılmasının ötesinde daha çok "para kazanmak" için yapıldığı öne sürülmektedir. Ayrıca engelliler, bu uygulamaların engellilere fayda sağlama bilincinin aksine engellilere karşı bakış açısını kötüleme ve engellileri mavi kapak gibi uygulamalara muhtaç konuma düşürdüklerine inanmaktadırlar:

"Hak verilmediği gibi, hukuk verilmediği gibi hiç kimsenin engellilerle ilgili ne tavanda, ne tabanda, ne yerelde, ne genelde hiçbir şekilde hukuki dayană̆ı olmayacak şekilde engelliler hala dolaşıyor. Mavi kapaklar da para kazanmak için engelli dünyamızı kullanıyorlar. Küçücük çocuklar da engelliye yardım etmek için pis kapakları yerlerden alıp mikrop kapıyor. Engelliyi bu kapağa muhtaç pozisyona buraktırdilar. Çocuklar topladılar bunları hatta bir tanesi bile ben teslim aldım. Sandalye almak için ama bu engellilere çocukların bakış açısını kötülüyor. Engelli bu mavi kapağa muhtaç. Başka türlü yardım edin. Milyarlar kazandılar mavi kapakları alıp satan ilgililer. Engelliye yansımadı. Bugün de dâhil" (E, 31, B).

Böylece, fizyolojik bir engel durumundan öte asıl engeli yaratabilecek olan bireye atfedilen 'acınan, dışlanan ve yetersiz görülen' şeklindeki olumsuz kültürel tanımlamalar, engelli bireyler için engelli olmayanların gözünden çizilen kültürel bir gösterge olmaktadır. Engelli bireylerin yaşadıkları toplumdaki sosyal tanımlamalar, toplumla bütünleşmede belirleyicidir. Bu bütünleşmede engelli bireye ilişkin genel kabullerin nasıl şekillendiği önemlidir. Bireylerin genel kabulleri, onların ortak duygu, düşünce ve pratikleri ile inşa edilen kültürel tanımları oluşturmaktadır. Engellilik sosyal ayrımcılığın belirli bir biçimidir. Bu ayrımcılığın kaynağında engelli bireylere yönelik oluşturulan kültürel tanımlamaların ya da kültürel resmetmenin hâkimiyetini unutmamak gerekmektedir (Burcu, 2011, s. 51-52).

Ses ve Jestler: İnsan vücudunun parçalarının insanlar arasındaki günlük etkileşimde önemli bir rol oynamakta ve bu da insan bedeninin önemini öne 
çıkarmaktadır. Yüz hatlarındaki oynamalar günlük hayatta hiç de dikkatimizi çekmeyen başka bir deyişle tamamen rutin olmuş birçok jest ve mimikler iletişim ve etkileşimde belirleyici bir rol oynamaktadır. Bir varlık olarak insan, vücudunu kullanarak günlük hayatında düzen kurmaya çalışmaktadır. Birçok duygu ve hisler bedendeki küçük hareketlenmelerle dile getirilmektedir. Bedenin özelliklerinin toplamı bir anlamda o kişinin kimliği de olmaktadır (Cirhinlioğlu, 2015, s. 83). Günlük iletişimdeki bu belirleyicilerin engellilerin bedenlerindeki farklılıkların dışında kendi kimliklerini nasıl inşa ettikleri bir kadın tarafında aşağıdaki örnekte ifade edilmektedir:

"Konuşma tavr olsun, davranışlan olsun, kişilere olan iletişimi olsun, ses tonu olsun. Ben bir espri ile oturdum masaya. Birtakım espriler yaptım. Çok hoşa gitti. Ben farkında değildim ama orada fark edildim" (K, 27, B).

Bu durum anlamın öznel inşasının, kesin bir şekilde bütün toplumsal bilgi stokunun ve insanların belirli bir çağda belirli bir toplum içinde doğmasının şekillendirdiği tarihsel birikiminin başlangıç noktasını göstermektedir. Engelli birey, diğer insanların yaşamlarından kaynaklanan birçok problemle de karşı karşıya kaldığından dolayı, bu problemlerin çözümü sadece öznel değil, aynı zamanda özneler-arası bir bağlamdan geçmektedir. Her iki problem de ilişkisel sosyal eylemden ileri gelmektedir. Bu nedenle çözümler, işaretler, araçlar, yapılar, ancak her şey bir yana bir dilin iletişim formları aracılığıyla nesnelleştirilebilmektedir. Böylelikle, diğerleri için de erişilebilir hale gelmektedir (Berger ve Luckmann, 2015, s. 24-25). Özneler arası bağlam içerisinde dilin iletişim formunu eş tercihi yaparken nasıl kullandığını bir erkek sözleriyle şu şekilde belirtmektedir:

"O paylaşım, o konuşma, vakit geçirme, ister istemez insanm bir anlık iletişimi vardır ya her şeyin başladığı, ondan itibaren de görüşme ile devam etti. Çünkü onun da sağllk sorunlar vardı, benim de sağllk sorunum vard. Şunun altını çizeyim, bizi birbirimize yaklaştıran şey sağllk sorunu değildi, sadece o bakış, o yüz ifadesi, mimiklerdi. Sonra birbirimizi biraz daha tanıdıktan sonra, biz bu hayatı yapabileceğimizi açı açı düşündük ve ondan sonra birbirimizi daha iyi tanıdığımıza emin olduktan sonra hayatlarımızı birleştirdik" (E, 39, E).

Burada da görüldüğü gibi engelli bireyler gündelik hayatı eyleyerek yaşamaktadır. Her eylemiyle de hayata yeni bir renk, yeni bir ses katmaktadır. Ama bu eylemini anlatması istendiğinde veya kendisi eylemini anlatmayı di- 
lediğinde eylemini ne kadar tarih ve kültürle bağlandırarak, onlarla hesaplaşarak anlatırsa, anlatması o kadar konuşma olmaktadır. Böylece, konuşması da o kadar anlamlı ve anlaşılır kılınmaktadır. Eylemi değerler dünyasında o denli ahlaki olarak nitelendirilmektedir. Çünkü o eylem konuşma dolayımıyla gerekçelendirilmekte, yorumlanmaktadır. Konuşmaya katılan taraflar birbirlerinin lakırdılarını ortaklaşa paylaştıkları söz dolayımıyla konuşma olarak algılamakta, deneyimlemektedirler (Çelebi, 2004, s. 203). Fakat bu söz dolayımıyla gerçekleşen ses ve konuşma algısının dışında engellilerin, toplumun kendilerine olan bakışını sözsüz iletişimde nasıl deneyimlediklerini bir kadın şöyle dile getirmektedir:

"Genelde biz engellileri gördükleri zaman sanki bir yaratıkmışı gibi insanlarımızın bakma tavirları var. Mesela ben genç kız olduğumda bu kolumun üstüne ceket atmadan dışarı çımazdım. Ceket atardım hani kamufle ederdim kolum gözükmesin diye" (K, 38, E).

Sonuç olarak denilebilir ki, iletişimde mesajlar sözlerle iletildiğinden daha çok, davranışlar ve ses tonu ile iletilmektedir. Ses tonu ve davranışlar sözler kadar kolay kontrol edilemezler. Bu nedenle duygu ve düşünceleri gerçeğe daha uygun ortaya koymaktadır. Beden, tavır, ses ve sözcüklerin iletişime ne kadar katkıda bulunduğunu belirlemek için yapılan çalışmalar sonucunda; mesajların \%60'ının bedenle, \%30'unun ses tonu ile \%10'unun sözcüklerle iletildiği belirlenmiştir. Sözsüz iletişimde insanlar, konuşma ya da yazı olmaksızın birbirlerine birtakım mesajlar iletmektedir. Bu iletişim şeklinde insanların ne söyledikleri değil, ne yaptıkları ve nasıl söyledikleri ön plana çıkmaktadır (Akpınar, 2004, s. 2).

\section{Sonuç}

Bu çalışmada, toplumsal değişme, kişiler arası sözsüz iletişim ve engellilik arasındaki ilişkinin ne şekilde ve nasıl olduğu Türkiye Sakatlar Derneği Sinop Şubesi örneği üzerinden analiz edilmektedir. Çalışmada elde edilen veriler doğrultusunda birinci olarak; "Toplumsal Değişme ve Beden Dili", ikinci olarak; "Kişiler Arası Sözsüz İletişim ve Engellilik" olmak üzere iki ana tema ve ikinci ana temada; "Göstergeler ve Yazı" ve "Ses ve Jestler" olmak üzere iki alt temaya ayrilıp betimlenmekte, yorumlanmakta ve değerlendirilmektedir. 
Birinci ana tema; toplumsal değişim sürecinde toplumun bedene bakışı ve engelli bireylerin kendi bedenlerini algılayışının önemli olduğunu ortaya koymaktadır. İnsanların birbirleri ile girmiş oldukları etkileşimde, bedenlerin hareketlerinin yanı sıra dil, sözcükler, ifadeler, işaretler gibi sembolik göstergeler önemli rol oynamaktadır. Ayrıca, "Özürüm bırakın benim özelliğim olsun" ifadesinde görüldüğ ü gibi engelli bireylerin bedenleri bir değişim ve gösterge değeri kazanmakta ve engellilik yeniden anlamlandırılmaktadır.

İkinci temanın "gösterge ve yazı" olarak belirlenen ilk alt temasında, haklar temelindeki değerlendirmeler, kanunlar, tüzükler ve yasa kişiler arası etkileşim aracı olarak kullanılan göstergeler olmaktadır. Engellilere göre bir gösterge aracı olarak kamu spotu uygulamasının kullanılarak kitle iletişim araçları vasıtasıyla toplumda kalıplaşmış belli yargıların önüne geçilmesi gerektiği düşüncesi önem taşımaktadır. Bir sosyal sorumluluk kampanyası olarak ortaya çıkan mavi kapak kampanyasının engellilerin yararına kullanılmak için yapılmasının ötesinde daha çok "para kazanmak" için yapıldığı öne sürülmektedir. Ayrıca, yaşlılar için gelir, sosyal hizmetler ve sağlık hizmetlerinin yeterli olmasının sağlanması gibi uygulamalar bakıma muhtaç engelliler açısından önemli bir gösterge niteliği taşımaktadır.

İkinci temanın "ses ve jestler" başlı̆̆ındaki alt temada ise, "Genelde biz engellileri gördükleri zaman sanki bir yaratıkmışız gibi insanlarımızın bakma tavırları var" ifadesinde görüldügü gibi toplumun inşa ettiği anlamların etkisiyle engellilerin özneler-arası bağlamdan uzaklaştırılması söz konusu olmaktadır. Böylece, sözsüz iletişim aracılığıyla toplumun engellilere konuşma ya da yazı olmaksızın birtakım mesajlar ilettiği görülmektedir. Mesajların nasıl ve ne şekilde iletildiği durumu, engellilerin anlam dünyasını önemli ölçüde etkilemektedir.

Sonuç olarak toplumsal değişim süreci içerisinde kişiler arası sözsüz iletişimde engellilik durumu anlamlı bir rol oynamaktadır. Bu süreçte engelliler, toplum tarafından inşa edilen sembolik evrenlerin birer parçası haline dönüşmektedirler. Burada, bu sembolik evrenlerin engelliler ve toplum açısından nasıl algılanıp anlamlandırıldığı her iki unsur açısından da belirleyici bir önem taşımaktadır. 


\title{
EXTENDED ABSTRACT
}

\section{Social Change, Interverbal Communication and Disability:Sinop TSD Example}

\author{
Ayşegül Demir \\ Sinop University
}

Social change refers to the transformation of the historical social world in which people exist. This world includes the social structure, social institutions, network of social relations, behavioral patterns, social norms and values. A large part of the daily communication where all this happens is through gestures, gestures or non-linguistic signs that are outside of the spoken language. As a dynamic of change, the individual is the main actor of modern society. There are two important dimensions of the new relationships that will socialize the self-centered ego of the individual in establishing new social bonds. The first is the development of self-confidence of the achievements and the social production of new spiritual resources that feed this self-confidence. The second is that it contributes to individual development by creating an individual-centered spiritual world of belief. Social relations also become reality with the supply of human bodies to society. The supply of bodies to the society or their place on the social stage is a very complex process. The body, in everyday life, social communication, power relations, class relations, etc. It is highly effective and can be influenced by the owner of the body and by different actors of the society and / or society to the extent desired.

Within these changes, the image of disability has had a medical meaning for a long time, with a solid and complete body perception that is considered normal outside of the social dimension. This understanding has changed with the spread of disability-related social movements. Face-to-face relationships and body language play an important role in this form of perception. Even though no words are spoken in these relationships, bodies speak. In structuring a face-to-face communication, mimics and gestures that form words, tone of voice and body language reveal that the role of body language in communication is important according to the characteristics of interpersonal relations and communication environment. In our age where non-verbal 
communication forms undergo change and transformation together with social change, it is important how disabled people perform social communication.

Social change refers to the transformation of the historical social world in which people exist. This world includes the social structure, social institutions, network of social relations, behavioral patterns, social norms and values. A large part of the daily communication where all this happens is through gestures, gestures or non-linguistic signs that are outside of the spoken language. These signs include interpersonal non-verbal communication styles that differ in the production and distribution of information in many variables from society to society, culture to culture, and gender. In this direction, the study aims to reveal the appearance of non-verbal communication between people in the process of social change in terms of disabled people.

Qualitative research, one of the sociological research methods, was used in the study to make sense of the situation of the hearing impaired. Qualitative data is seen as an undeniably attractive research method. Words, the most common form of qualitative data so far, are a special feature of people and organizations. Purposeful sampling is used as a sample. Choosing a purposeful sample suitable for the research, taking into account factors such as purpose, similarity, difference and diversity; the research subject, question, and problem is to get a holistic picture. The sample of the study consisted Turkey Disabled Association members with disabilities in the province of Sinop. The use of problem-centered interview technique is considered appropriate as a qualitative data collection technique in the study. Problem-centered interview chooses the way of conversation in order to see the subjective meanings in the light of one's own formulations. Turkey Disabled Association (TSD) as a member of the Sinop Branch of the total, nine people (three women and six men) with in-depth unstructured interviews were conducted.

Descriptive recording, chosen as a data processing technique, is made by adhering to the original forms of the data in interview solutions, by making a descriptive analysis by making direct quotations from what the individuals say, and by presenting the data with a descriptive approach. Data interpretation stage is done with selective coding used in the analysis of the grounded theory. At this stage, the researcher deliberately determines a feature as the 
main category and concentrates on it. Coding technique is used when transferring data in interviews and coding is done according to gender, age and marital status.

In the first of the findings obtained from the interviews during the analysis of the data, "social change and body language"; The second one consists of two main themes: "interpersonal non-verbal communication and disability". In the second main theme, it is divided into two sub-themes: "signs and writing" and "voice and gestures", and they are described, interpreted and evaluated. The first main theme determined as social change and body language; In the process of social change, symbolic indicators such as language, words, expressions and signs play an important role in the interaction of people with each other in the way the society looks at the body and the disabled individuals perceive their own bodies. In the first domain of the second main theme identified as interpersonal non-verbal communication and disability, which is determined as "indicator and writing", rights-based evaluations, laws, regulations and laws are indicators used as a means of interpersonal interaction. According to the disabled, the idea that certain stereotypes in society should be avoided by using the public service announcement application as an indicator tool is important. Under the title of "voice and gestures", which is determined as the second sub-theme, it is possible to remove the disabled people from the inter-subject context with the effect of the meanings built by the society.

As a result, disability plays a significant role in interpersonal nonverbal communication in the process of social change. In this process, people with disabilities become part of the symbolic universes built by the society. Here, how these symbolic universes are perceived and interpreted in terms of disabled people and society is of decisive importance for both factors.

\section{Kaynakça / References}

Akerson, F. (2005). Göstergebilime giriş. İstanbul: Multilingual Yayınları.

Akgül, K. (2006). Kişilerarası iletişimde dans ve beden dili işlevini etkileyen etmenler ve bir alan araştırması. Yayımlanmamış doktora tezi, Selçuk Üniversitesi Sosyal Bilimler Enstitüsü, Konya.

Akpınar, R. (2004). Duygusal yüz ifadelerini anlama becerisini geliştirmeye yönelik örnek bir öğretim programı. Uluslararası İnsan Bilimleri Dergisi, 1(1), 110. 
Aydın, O. ve Baran G. (2010). Toplumsal değişme sürecinde evlenme ve boşanma. Toplum ve Sosyal Hizmet, 21(2), 117-126.

Bat, M. (2015). Plastik kapak toplamaya yönelik kurumsal sosyal sorumluluk kampanyalarının karşılaştırmalı analizi. Uluslararası İktisadi ve İdari Incelemeler Dergisi, 15, 1-20.

Berger, P. L. ve Luckmann, T. (2015). Modernite, çoğulculuk ve anlam krizi modern insanın yönelimi. M. D. Dereli (Çev.). Ankara: Heretik Yayınları.

Bilgin, N. (2006). Sosyal bilimlerde içerik analizi teknikler ve örnek çalışmalar. Ankara: Siyasal Kitabevi.

Burcu, E. (2006). Özürlülük kimliği ve etiketlemenin kişisel ve sosyal söylemleri. Hacettepe Üniversitesi Edebiyat Fakültesi Dergisi, 23(2), 61-83.

Cirhinlioğlu, Z. (2015). Sağlık sosyolojisi. Ankara: Nobel Akademik Yayıncılık.

Çabuklu, Y. (2004). Toplumsalın sinırında beden. İstanbul: Kanat Kitap.

Çelebi, N. (2004). Sosyoloji ve metodoloji yazıları. Ankara: Anı Yayıncılı.

Güven, F. (2019). Medya Kahramanı İle Kurulan Parasosyal Etkilrşim Bağlamında Kültür ve Sürdürebilirliği. Motif Vakfı, 12(28), 956-969.

Kemaloğlu, Y. (2014). Engellilik, kulak burun boğaz (KBB) hekimliği ve işaret dili. Bozok Tıp Dergisi, 1(1), 38-53.

Kıssal, A. ve Beşer, A. (2009). Yaşlı istismar ve ihmalinin değerlendirilmesi. TAF Preventive Medicine Bulletin, 8(4), 357-364.

Kocasavaş, Y. (2007). Etkili iletişimin sözsüz adımı olan beden dili ve Türkçe eğitimindeki rolü. Hasan Ali Yücel Eğitim Fakültesi Dergisi, 7, 45-47.

Küçüközyiğit, M. S. ve Şafak, P. (2015). Arttırıcı ve alternatif iletişim teknikleri. Journal of Instructional Technologies \& Teacher Education, 4(1), 27-37.

Kümbetoğlu, B. (2005). Sosyolojide ve Antropolojide niteliksel yöntem ve araştırma. İstanbul: Bağlam Yayınları.

Macionis, J. J. (2015). Sosyoloji. V. Akan (Çev.). Ankara: Nobel Akademik Yayıncilık.

Mayring, P. (2011). Nitel sosyal araştırmaya giriş. Ankara: BilgeSu Yayıncılık.

Okumuş, E. (2009). Bedene müdahalenin sosyolojisi. Şarkiyat İlmi Araştırmalar Dergisi, 2, 45-66.

Punch, K. F. (2014). Sosyal araştırmalara giriş nicel ve nitel yaklaşımlar (3. Baskı). D. Bayrak, H. B. Arslan ve Z. Akyüz (Çev.). Ankara: Siyasal Kitabevi.

Engellilerin Haklarına İlişkin Sözleşme, Bakanlar Kurulu Kararı (14/07/2009). Resmi Gazete, sayıs1: 27288.

Robson, C. (2015). Bilimsel araştırma yöntemleri gerçek dünya araştırması. Ş. Çınkır ve N. Demirkasımoğlu (Çev.). Ankara: Anı Yayınları. 
Seggie, F. ve Bayyurt, Y. (2015). Nitel Araştırma yöntem, teknik, analiz ve yaklaşımları. Ankara: Anı Yayıncilı.

Uluocak, Ş., ve Aslan, C. (2012). Toplum ve engelliler. Çanakkale: Çanakkale Kitaplığı.

Yaman, F. ve Göçken, İ. (2015). Kamu spotu reklamlarının sigara kullanıcıları üzerindeki etkisi: Afyonkarahisar ilinde bir uygulama. KAÜ İ̈BF Dergisi, 6(11), 53-66.

\section{Kaynakça Bilgisi / Citation Information}

Demir, A. (2021). Toplumsal değişme, kişiler arası sözsüz iletişim ve engellilik. OPUS-Uluslararası Toplum Araştırmaları Dergisi, 17(33), 112-131. DOI: 10.26466/opus.836347 